\title{
Consumer Acceptability and Commercialization of Bamboo Shoot Tart
}

\author{
Jefferson N. Curammeng, France Marie Ann R. Tacadena*, Jonathan N. Tariga, Mary Joy A. Roldan \\ College of Hospitality Industry Management, Quirino State University, Diffun, 3401, Quirino, Philippines
}

Received May 24, 2021; Revised September 16, 2021; Accepted October 20, 2021

\begin{abstract}
Cite This Paper in the following Citation Styles
(a): [1] Jefferson N. Curammeng, France Marie Ann R. Tacadena, Jonathan N. Tariga, Mary Joy A. Roldan, "Consumer Acceptability and Commercialization of Bamboo Shoot Tart," Food Science and Technology, Vol. 9, No. 4, pp. 77 - 86, 2021. DOI: 10.13189/fst.2021.090402.
\end{abstract}

(b): Jefferson N. Curammeng, France Marie Ann R. Tacadena, Jonathan N. Tariga, Mary Joy A. Roldan (2021). Consumer Acceptability and Commercialization of Bamboo Shoot Tart. Food Science and Technology, 9(4), 77 - 86. DOI: 10.13189/fst.2021.090402.

Copyright $\subseteq 2021$ by authors, all rights reserved. Authors agree that this article remains permanently open access under the terms of the Creative Commons Attribution License 4.0 International License

\begin{abstract}
Bamboo shoot tart is a type of short crust pastry produced from Bambusa vulgaris' juvenile shoot, known as kiling. In some distinguished food establishments, Tart is typically eaten as a petit four and not so popular in the public. In order to alleviate food scarcity and at the same time to produce a healthy organic food, the production of bamboo shoot tart can have a practical effect not only for potential investors but also for bamboo farmers. This study was conducted to assess the sensory quality of Bamboo Shoot Tart as perceived by the consumers with the following objectives: (1) to determine the profile of the respondents as to sex, civil status, ethnic affiliation, age, and highest educational attainment; (2) to assess the sensory quality of the developed bamboo shoot tart as perceived by the respondents in terms of appearance, color, texture, aroma, presentation, and taste; (3) to verify if there are significant differences on the sensory evaluation of Bamboo Shoot Tart when respondents are grouped by sex, civil status, ethnic affiliation, age, and highest educational attainment along appearance, color, texture, aroma, presentation, and taste, and (4) to analyze the cost benefit of bamboo shoot products. Data were tabulated, analyzed, and interpreted using frequency, percent, mean, t-test, and ANOVA. The result showed that there are significant differences on the sensory quality of Bamboo Shoot Tart as to color when respondents are grouped by sex and age, as to texture when grouped by ethnic affiliation and along texture and taste when respondents are grouped by highest educational attainment. Ergo, the incorporation of bamboo shoots in a shortcrust
\end{abstract}

tart is widely acceptable among the different types of consumers.

Keywords Bamboo Shoot, Tart, Sensory Evaluation, Appearance, Texture

\section{Introduction}

Pastry is a dough which can be savoury or sweetened with flour, water and shortening. Sweetened pastries are also defined as the confectionery of bakers. Many types of baked goods made from ingredients such as flour, sugar, milk, butter, shortening, baking powder, and eggs are implied by the term 'pastries.'

It is possible to translate the French word tarte into either pie or tart, as both are mainly the same, with the exception of a pie usually covering the pastry filling, whereas flans and tarts leave it open. Tart is a baked dish consisting of a filling over a pastry base with an open top not filled with pastry, according to Davison Allan [1], the Oxford companion to cooking. Typically, tart is a short crust pastry; the filling can be sweet or savory, while modern tarts are usually fruit-based, often sweet or savory.

Bamboo shoot tart is a type of short crust pastry developed from the juvenile shoot known as kiling of Bambusa Vulgaris. Tart is usually eaten as a petit four in some distinguished food establishments and is not so popular among the public. The production of bamboo shoot 
tarts can have a practical effect not only on potential investors but also on bamboo farmers.

According to the study of Choudhury et al. [2], and Tariga [3], bamboo shoot is low in cholesterol and fat but high in potassium, carbohydrate and dietary fats. The rare kind of this edible bamboo shoots is used in different types of cuisines because it has a matchless taste and flavour. Also, bamboo can be used in manufacturing other products and canned goods [4, 5]. Also, Asian countries utilize bamboo shoots as food and for economic purposes [6].

The consumption and encouragement of indigenous diets could help alleviate malnutrition and mitigate food insecurity in developing countries [7]. Meanwhile, in many ways, bamboo shoots promote health benefits including improving digestion, alleviating hypertension and preventing cardiovascular disease and cancer [8]. Few studies reveal its richness in nutritive components including protein and fiber content and thus the bamboo shoot can be useful to address the problems of malnutrition [9]. Fiber helps to regulate cholesterol levels and plays a part in colon cancer prevention [10]. Several workers have analysed the nutrient compositions of shoots of various edible bamboo plants [11-15]. As a result of its health-promoting effects, bamboo shoots can have a high dietary fiber content, according to Yang [16] et al., Bamboo shoot fibers may have a dry weight of about 40 percent greater than the most widely consumed vegetables. The dietary fiber is mainly insoluble, representing 60-90 percent of their total carbohydrates $[17,18]$. For decades, bamboo shoots have been used by the tribal world as an ideal vegetable for a healthy diet [19], being low in fat, high in nutrients and abundant in mineral content [20].

Bamboo shoots have been reported as being associated with a variety of health benefits such as antioxidant, anti-free radical, anti-aging, anti-cancer, cardiovascular disease prevention, weight loss, digestive improvement, blood pressure decrease, and anti-microbial activity due to the presence of various flavones, glycosides [21]. There are healthy concentrations of thiamine, niacin, vitamin A, vitamin B6, and vitamin $\mathrm{E}$ in the freshly collected bamboo shoots [22,23].

In order to characterize the properties of the bamboo shoot fiber, especially its physiological effects, very limited studies have been done. Extraordinary water and oil binding capacities were shown by dietary fiber isolated from the bamboo shoot, as well as cholesterol and bile acid binding capacities [24]. S. K., according to Tomar. [25], in traditional Asian medicine, bamboo plants play a significant role, especially in China and Japan. Due to the interests of numerous research groups supporting their dietary principles and well-being [26], the utility of bamboo shoots as health foods has been recognized in the recent past.
The HNRDA is aligned with AmBisyon Natin 2040: matatag, maginhawa at panatag na buhay para sa lahat. It has three pillars: Malasakit (enhancing the social fabric), Pagbabago (reducing inequality) and Kaunlaran (increasing potential growth). AmBisyon Natin 2040 and the three pillars form the foundation for more inclusive growth, a high-trust and resilient society and a globally competitive knowledge economy. Bamboo was identified as one of the priority products including its young culm [27].

Previous studies on bamboo shoots have been reported and cited, but still a lot more products are waiting to be produced in order to exploit the prospective of bamboo and to respond to the harmonized national research and development agenda of 2017-2022 by governments. Because of the health benefits of bamboo shoots discussed, a new trend in the promotion of bamboo shoot products is then conceptualized by infusing these raw materials as a primary ingredient in the production of bamboo shoot tart and other types of pastries, bread and cakes.

The shelf life of bamboo shoots is limited and must be sold immediately after harvesting. They are sold in different processed shapes and are available in versions that are fresh, dried, fermented, pickled and canned [28]. Due to seasonal availability of bamboo shoots, processing for handling cynogenic toxicity in raw shoots while keeping nutrients intact and enhancement of shelf life of the value-added products assume great significance for business potential [29]. Clean-label specialist Ulrick and Short is producing a flexible fiber that has potential for the gluten-free market, harvested from bamboo shoots. The supplier of ingredients said that for bakery applications, the bamboo fiber had good potential, including the prolongation of shelf-life, which may assist producers to increase profits in the gluten-free area [30].

\section{Objectives of the Study}

The study was conducted (1) to determine the profile of the respondents in terms of sex, civil status, ethnic affiliation, age, and highest educational attainment; (2) to assess the sensory quality of the developed bamboo shoot tart as perceived by the respondents in terms of appearance, color, texture, aroma, presentation, and taste; (3) to verify if there are significant differences on the sensory evaluation of Bamboo Shoot Tart when respondents are grouped by sex, civil status, ethnic affiliation, age, and highest educational attainment along appearance, color, texture, aroma, presentation, and taste and; (4) to determine the cost benefit analysis and calorie content evaluation of bamboo shoot tart. 


\section{Methodology}

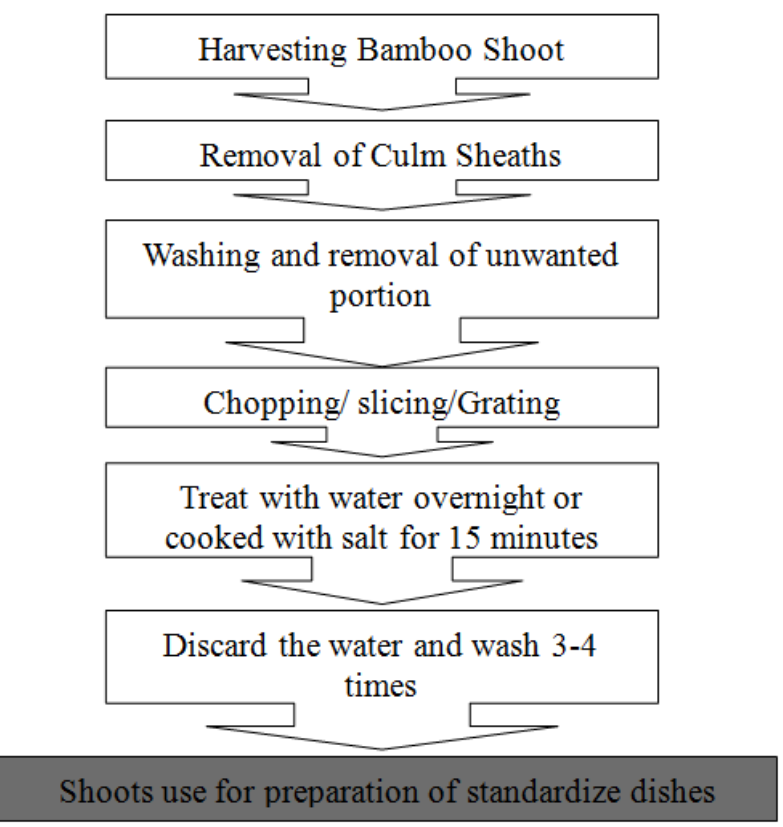

Figure 1. Processing and preservation techniques for bamboo shoots

Table 1. Preparation of Bamboo shoot

\begin{tabular}{|c|c|}
\hline \multicolumn{2}{|c|}{ Materials } \\
\hline Oven & Baking pans \\
\hline Spatula & Wire Whisk \\
\hline Mixing Bowl & Tart Molder \\
\hline Utility bowls & Knife \\
\hline Baking sheet & \\
\hline \multicolumn{2}{|c|}{ Ingredients } \\
\hline For the Crust & For the Tart Filling \\
\hline $140 \mathrm{~g}$ Butter & 1 pc. Egg \\
\hline 1 pc. Egg & $1 / 2$ cup White Sugar \\
\hline $1 / 2$ cup confectioners powdered sugar & $1 / 3$ cup maple syrup or corn syrup \\
\hline 1 cup plain flour & 1tbsp. Melted Butter \\
\hline $1 / 2$ cup bamboo shoot powder & $1 / 2$ tsp. Vanilla extract \\
\hline Pinch of salt & 1 cup finely shredded bamboo shoot \\
\hline \multicolumn{2}{|c|}{ Procedure } \\
\hline \multicolumn{2}{|c|}{$\begin{array}{l}\text { Mix sifted flour, bamboo shoot powder, icing sugar, salt, butter and egg in a bowl until dough and kneading is finished. } \\
\text { Sprinkle the work area with some flour and knead it to form a ball and wrap it in a film that clings. }\end{array}$} \\
\hline \multicolumn{2}{|c|}{ For around 25 to 30 minutes, refrigerate the dough or until it is workable. } \\
\hline \multicolumn{2}{|c|}{ Combine all the filling ingredients for 10 minutes or until they become sticky, then set aside to make the bamboo shoot filling. } \\
\hline \multicolumn{2}{|l|}{ Preheat the oven to $180 \mathrm{C}(350 \mathrm{~F})$. } \\
\hline \multicolumn{2}{|c|}{ Cut 24 equal portions when the dough is ready and flatten each pastry ball on a flour and put each dough on a prepared tart mould. } \\
\hline \multicolumn{2}{|c|}{ By circular motion, press dough in the molder, use your thumbs and clean up the edges with your index fingers. } \\
\hline \multicolumn{2}{|c|}{ To get rid of air pockets and keep the dough from shrinking while baking, poke the dough with a fork. } \\
\hline \multicolumn{2}{|c|}{ Prepare the filling and pour on each mold around 2/3's complete. } \\
\hline \multicolumn{2}{|c|}{$\begin{array}{l}\text { Place bamboo shoot tarts on a baking tray and bake for around } 20-25 \text { minutes in a preheated oven or until the pastry becomes light brown } \\
\text { and the filling becomes firm. }\end{array}$} \\
\hline \multicolumn{2}{|c|}{ Remove tarts from the oven and allow them to cool completely before removing them from the molder to avoid cracking. } \\
\hline needed, you can wrap it in any colored cellophan & \\
\hline
\end{tabular}




\section{Statistical Treatment of Data}

In evaluating the sensory quality of Bamboo Food Tart as to appearance, color, texture, aroma, presentation, and taste, a four-point Likert was used which is as follows:

\begin{tabular}{|c|c|c|}
\hline Scale & Range & Indicator \\
\hline 4 & $3.25-4.00$ & $\begin{array}{c}\text { The respondent likes the quality of the } \\
\text { product to the maximum level. }\end{array}$ \\
\hline 3 & $2.50-3.24$ & $\begin{array}{r}\text { The respondent likes the quality of the } \\
\text { product to a high extent. }\end{array}$ \\
\hline 2 & $1.75-2.49$ & $\begin{array}{c}\text { The respondent likes the quality of the } \\
\text { product to an average extent. }\end{array}$ \\
\hline 1 & $1.00-1.74$ & $\begin{array}{c}\text { The respondent likes the quality of the } \\
\text { product to a less extent. }\end{array}$ \\
\hline
\end{tabular}

\section{Statistical Tools Used}

Data were tabulated, analyzed, and interpreted using the following tools:

Frequency and Percent. These were utilized to determine the profile of the respondents as to sex, civil status, ethnic affiliation, age, and highest educational attainment.

Mean. This was used to assess the sensory quality of Bamboo Shoot Tart as perceived by the respondents.

t-test. This was utilized to find out if there are significant differences on the sensory evaluation of Bamboo Shoot Tart when respondents are grouped by sex, civil status, and highest educational attainment.

ANOVA. This was used to verify if there are significant differences on the sensory evaluation of the respondents as to ethnic affiliation and age.

RESULTS AND DISCUSSIONS This chapter presents the frequency distribution of the respondents, mean sensory evaluation of Bamboo Shoot Tart, and the tests of significant differences on the mean sensory evaluation of the product when respondents are grouped by profile.

\section{Profile of the Respondents}

Table 2. Frequency Distribution of the Respondents as to Profile

\begin{tabular}{|c|c|c|}
\hline \multirow{2}{*}{ PROFILE } & PARTICULARS & FREQUENCY \\
\hline \multirow{3}{*}{ Civil Status } & Male & 35 \\
\cline { 2 - 3 } & Female & 65 \\
\hline \multirow{4}{*}{$\begin{array}{c}\text { Ethnic } \\
\text { Affiliation }\end{array}$} & Married & 7 \\
\cline { 2 - 3 } & Single & 93 \\
\cline { 2 - 3 } & Tagalog & 13 \\
\hline \multirow{4}{*}{\begin{tabular}{c} 
Age (in years) \\
\cline { 2 - 3 }
\end{tabular}} & Ilocano & 60 \\
\cline { 2 - 3 } & Yogad/Bago/Igorot & 18 \\
\cline { 2 - 3 } & 20 - 22 & 9 \\
\hline \multirow{2}{*}{$\begin{array}{c}\text { Highest } \\
\text { Educational } \\
\text { Attainment }\end{array}$} & College Level & 42 \\
\cline { 2 - 3 } & High School Level/ & 49 \\
\hline
\end{tabular}

$\mathrm{n}=100$

Table 2 shows the frequency distribution of the 100 respondents as to profile. As revealed, 35 respondents are male while 65 are female. In terms of civil status, seven (7) are married and 93 respondents are single. As to ethnic affiliation, 13 are Tagalog, 60 are Ilocano, 18 are Ifugao, and nine (9) respondents are Bago, Yogad and Igorot. In terms of age, 42 respondents are 17 - 19 years old, 49 are 20 - 22 years old, and nine (9) are 23 years old \& above. As to highest educational attainment, 90 respondents are in College and 10 are in high school or Master Degree Holder.

Based on the table, most of the respondents are female, single, Ilocano, 20 - 22 years old, and in college. 


\section{Mean Sensory Evaluation of Bamboo Shoot Tart}

Table 3. Mean Sensory Evaluation of Bamboo Shoot Tart when Respondents are Grouped by Sex and Civil Status

\begin{tabular}{|c|c|c|c|c|c|c|c|c|c|c|}
\hline \multirow{3}{*}{ Item } & \multirow{2}{*}{\multicolumn{2}{|c|}{$\mathrm{n}=100$}} & \multicolumn{4}{|c|}{ Sex } & \multicolumn{4}{|c|}{ Civil Status } \\
\hline & & & \multicolumn{2}{|c|}{ Male } & \multicolumn{2}{|c|}{ Female } & \multicolumn{2}{|c|}{ Married } & \multicolumn{2}{|c|}{ Single } \\
\hline & Mean & Description & Mean & Description & Mean & Description & Mean & Description & Mean & Description \\
\hline Appearance & 3.18 & LVM & 3.18 & LVM & 3.18 & LVM & 3.18 & LVM & 3.18 & LVM \\
\hline Color & 3.31 & LE & 3.20 & LVM & 3.37 & LE & 3.20 & LVM & 3.37 & LE \\
\hline Texture & 3.09 & LVM & 3.20 & LVM & 3.03 & LVM & 3.20 & LVM & 3.03 & LVM \\
\hline Aroma & 3.10 & LVM & 3.91 & LE & 3.20 & LVM & 2.91 & LVM & 3.20 & LVM \\
\hline Presentation & 3.25 & LE & 3.00 & LVM & 3.38 & $\mathrm{LE}$ & 3.00 & LVM & 3.38 & LE \\
\hline Taste & 3.64 & LE & 3.57 & LE & 3.68 & LE & 3.57 & LE & 3.68 & LE \\
\hline
\end{tabular}

Legend: 3.25 - 4.00 Like Extremely (LE) 2.50 - 3.24 Like Very Much (LVM) 1.75 - 2.49 Like Moderately (LM) 1.00 - 1.74 Like Slightly (LS)

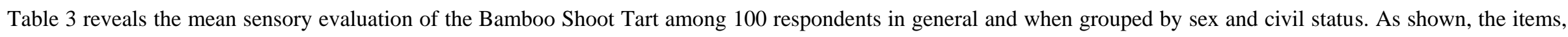

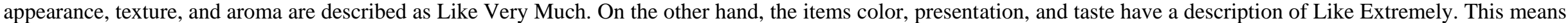

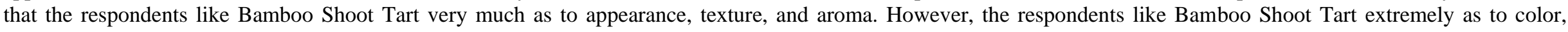
presentation, and taste.

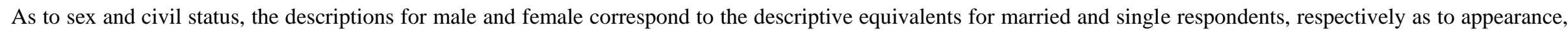

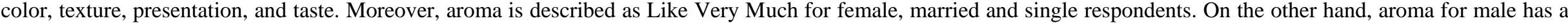

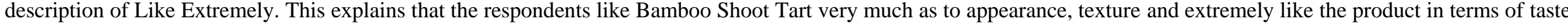

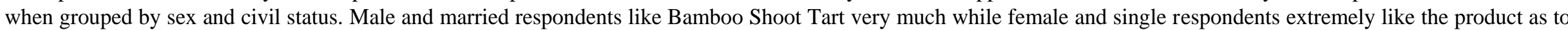

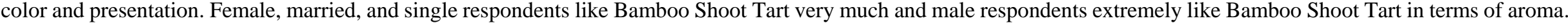


Table 3a. t-test on the Mean Sensory Evaluation of Bamboo Shoot Tart when Respondents are Grouped by Sex

\begin{tabular}{|c|c|c|c|}
\hline Item & t-computed & p-value & Decision \\
\hline Appearance & 2.047 & .156 & Accept Ho \\
\hline Color & $4.723^{*}$ & .032 & Reject Ho \\
\hline Texture & .954 & .331 & Accept Ho \\
\hline Aroma & .535 & .466 & Accept Ho \\
\hline Presentation & .110 & .741 & Accept Ho \\
\hline Taste & .442 & .508 & Accept Ho \\
\hline
\end{tabular}

p-value of .05 and below are significant and above .05 are not significant

T-test on the mean sensory evaluation of Bamboo Shoot Tart when respondents are grouped by sex is shown in Table 3a. As revealed, only the item color is found to have a significant result which implies that the mean sensory evaluation of Bamboo Shoot Tart varies between male and female respondents as to color.
Table 3b. t-test on the Mean Sensory Evaluation of Bamboo Shoot Tart when Respondents are Grouped by Civil Status

\begin{tabular}{|c|c|c|c|}
\hline Item & t-computed & p-value & Decision \\
\hline Appearance & 1.048 & .309 & Accept Ho \\
\hline Color & 1.401 & .239 & Accept Ho \\
\hline Texture & 1.521 & .220 & Accept Ho \\
\hline Aroma & .501 & .481 & Accept Ho \\
\hline Presentation & .003 & .960 & Accept Ho \\
\hline Taste & .126 & .723 & Accept Ho \\
\hline
\end{tabular}

Table $3 b$ reveals the $t$-test on the mean sensory evaluation of Bamboo Shoot Tart when respondents are grouped by civil status. Based on the table, no item is found to have a significant result. Thus, the mean sensory evaluation of Bamboo Shoot Tart does not differ between married and single respondents as to appearance, color, texture, aroma, presentation, and taste.

Table 4. Mean Sensory Evaluation of Bamboo Shoot Tart when Respondents are Grouped by Ethnic Affiliation

\begin{tabular}{|c|c|c|c|c|c|c|c|c|}
\hline \multirow{2}{*}{ Item } & \multicolumn{2}{|c|}{ Tagalog } & \multicolumn{2}{c|}{ Ilocano } & \multicolumn{2}{c|}{ Ifugao } & \multicolumn{2}{c|}{ Bago/Yogad/Igorot } \\
\cline { 2 - 11 } & M & D & M & D & M & D & M & D \\
\hline Appearance & 2.77 & LVM & 3.20 & LVM & 3.28 & LE & 3.44 & LE \\
\hline Color & 3.23 & LVM & 3.28 & LE & 3.39 & LE & 3.44 & LE \\
\hline Texture & 3.23 & LVM & 3.12 & LVM & 2.67 & LVM & 3.56 & LE \\
\hline Aroma & 2.85 & LVM & 3.23 & LVM & 2.83 & LVM & 3.11 & LVM \\
\hline Presentation & 2.92 & LVM & 3.38 & LE & 3.11 & LVM & 3.11 & LVM \\
\hline Taste & 3.85 & LE & 3.62 & LE & 3.44 & LE & 3.89 & LE \\
\hline
\end{tabular}

The mean sensory evaluation of Bamboo Shoot Tart when respondents are grouped by ethnic affiliation is shown in Table 4. As revealed, the item taste for Tagalog; the items color, presentation, and taste for Ilocano; the items appearance, color, and taste for Ifugao; and the items appearance, color, texture, and taste for Bago, Yogad, and Igorot are described as Like Extremely. This means that Tagalog respondents like Bamboo Shoot Tart extremely as to taste; Ilocano along color, presentation, and taste; Ifugao as to appearance, color, and taste; and Bago, Yogad, and Igorot along appearance, color, texture, and taste.

Table 4a. ANOVA on the Mean Sensory Evaluation of Bamboo Shoot Tart when Respondents are Grouped by Ethnic Affiliation

\begin{tabular}{|c|c|c|c|}
\hline Item & F-computed & p-value & Decision \\
\hline Appearance & 1.310 & .276 & Accept Ho \\
\hline Color & .203 & .894 & Accept Ho \\
\hline Texture & $2.887 *$ & .040 & Reject Ho \\
\hline Aroma & 1.549 & .207 & Accept Ho \\
\hline Presentation & 1.291 & .282 & Accept Ho \\
\hline Taste & 1.101 & .353 & Accept Ho \\
\hline
\end{tabular}

ANOVA on the mean sensory evaluation of Bamboo shoot Tart when respondents are grouped by ethnic affiliation is presented in Table 4a. As shown, only the item "texture" has a significant result, which implies that the mean sensory evaluation of Bamboo shoot Tart differs among the respondents as to texture. 
Table 5. Mean Sensory Evaluation of Bamboo Shoot Tart when Respondents are Grouped by Age

\begin{tabular}{|c|c|c|c|c|c|c|}
\hline \multirow{2}{*}{ Item } & \multicolumn{2}{|c|}{$\mathbf{1 7} \mathbf{- 1 9}$} & \multicolumn{2}{c|}{$\mathbf{2 0 - 2 2}$} & \multicolumn{2}{c|}{ 23 and above } \\
\cline { 2 - 7 } & Mean & Description & Mean & Description & Mean & Description \\
\hline Appearance & 3.29 & LE & 3.16 & LVM & 2.78 & LVM \\
\hline Color & 3.57 & LE & 3.16 & LVM & 2.89 & LVM \\
\hline Texture & 3.24 & LVM & 3.06 & LVM & 2.56 & LVM \\
\hline Aroma & 3.24 & LVM & 3.02 & LVM & 2.89 & LVM \\
\hline Presentation & 3.40 & LE & 3.20 & LVM & 2.78 & LVM \\
\hline Taste & 3.74 & LE & 3.57 & LE & 3.56 & LE \\
\hline
\end{tabular}

Table 5 shows the mean sensory evaluation of Bamboo Shoot Tart when respondents are grouped by age. Based on the table, the items appearance, color, presentation, and texture for 17 - 19 years old; and the item taste for 20 - 22 and 23 years old \& above are described as Like Extremely. This means that the respondents who are 17 - 19 years old like Bamboo Shoot Tart extremely as to appearance, color, presentation, and texture; and the respondents who are $20-22$ and 23 years old \& above like Bamboo Shoot Tart extremely along taste.

Table 5a. ANOVA on the Mean Sensory Evaluation of Bamboo Shoot Tart when Respondents are Grouped by Age

\begin{tabular}{|c|c|c|c|}
\hline Item & F-computed & p-value & Decision \\
\hline Appearance & 1.257 & .289 & Accept Ho \\
\hline Color & $4.628^{*}$ & .012 & Reject Ho \\
\hline Texture & 2.734 & .070 & Accept Ho \\
\hline Aroma & 1.087 & .341 & Accept Ho \\
\hline Presentation & 2.0853 & .134 & Accept Ho \\
\hline Taste & .624 & .538 & Accept Ho \\
\hline
\end{tabular}

Table 5a reveals the ANOVA on the mean sensory evaluation of Bamboo Shoot tart when respondents are grouped by age. As shown, only the item "color" is found to have a significant result. This implies that the mean sensory evaluation of Bamboo Shoot Tart differs among 17 - 19, $20-22$, and 23 years old \& above as to color.

Table 6. Mean Sensory Evaluation of Bamboo Shoot Tart when Respondents are Grouped by Highest Educational Attainment

\begin{tabular}{|c|c|c|c|c|}
\hline \multirow{2}{*}{ Item } & \multicolumn{2}{|c|}{ College Level } & \multicolumn{2}{c|}{$\begin{array}{c}\text { High School/Master } \\
\text { Degree Holder }\end{array}$} \\
\cline { 2 - 5 } & Mean & Description & Mean & Description \\
\hline Appearance & 3.22 & LVM & 2.80 & LVM \\
\hline Color & 3.33 & LE & 3.10 & LVM \\
\hline Texture & 3.14 & LVM & 2.60 & LVM \\
\hline Aroma & 3.10 & LVM & 3.10 & LVM \\
\hline Presentation & 3.24 & LVM & 3.30 & LE \\
\hline Taste & 3.61 & LE & 3.90 & LE \\
\hline
\end{tabular}

The mean evaluation of Bamboo Shoot Tart when respondents are grouped by highest educational attainment, the respondents' mean evaluation of Bamboo Shoot Tart is revealed in Table 6 . As presented, the items color and taste for college level and the items presentation and taste for high school level and Master Degree Holder have a description of Like Extremely. Thus, college level respondents like Bamboo shoot Tart extremely as to color and taste. On the other hand, the respondents who are in high school and Master Degree Holder like the product extremely along with presentation and taste.
Table 6a. t-test on the Mean Sensory Evaluation of Bamboo Shoot Tart when Respondents are Grouped by Highest Educational Attainment.

\begin{tabular}{|c|c|c|c|}
\hline Item & t-computed & p-value & Decision \\
\hline Appearance & .082 & .775 & Accept Ho \\
\hline Color & 3.245 & .075 & Accept Ho \\
\hline Texture & $10.309^{*}$ & .002 & Reject Ho \\
\hline Aroma & .302 & .584 & Accept Ho \\
\hline Presentation & .440 & .509 & Accept Ho \\
\hline Taste & $5.902 *$ & .017 & Reject Ho \\
\hline
\end{tabular}

Table $6 a$ presents the t-test on the mean sensory evaluation of Bamboo shoot Tart when respondents are grouped by highest educational attainment. Based on the table, the items "texture" and "taste" have significant results. Thus, the null hypothesis is rejected, which implies that the mean sensory evaluation of Bamboo Shoot Tart varies between college level and high school level/Master Degree Holder along texture and taste.

Table 7. Cost benefit Analysis of bamboo shoot tart

\begin{tabular}{|c|c|c|}
\hline Ingredients & Quantity & Unit Price (Php) \\
\hline For the crust & & \\
\hline butter & $140 \mathrm{~g}$ & 55.00 \\
\hline egg & 1 & 5.00 \\
\hline confectioners powdered sugar & $1 / 2$ cup & 20.00 \\
\hline plain flour & 1 cup & 10.00 \\
\hline bamboo shoot powder & $1 / 2$ cup & 10.00 \\
\hline salt & pinch & 1.00 \\
\hline For the filling & & 10.00 \\
\hline egg & $11 / 2$ & 10.00 \\
\hline sugar & $1 / 2$ cup & 15.00 \\
\hline maple syrup or corn syrup & $1 / 3$ cup & 2.00 \\
\hline melted butter & 1 tbsp. & 1.00 \\
\hline vanilla extract & $1 / 2$ tsp. & 10.00 \\
\hline finely shredded bamboo shoot & 1 cup & 149.00 \\
\hline TOTAL EXPENSES & & \\
\hline
\end{tabular}


Table 8. Nutrient Content of bamboo shoot tart

\begin{tabular}{|c|c|c|}
\hline Product & Quantity & Total \\
\hline Bamboo Shoot Tart & $24 \times 12$ & 288.00 \\
\hline Expenses & & 149.00 \\
\hline Gross Income & & Php 139.00 \\
\hline
\end{tabular}

The nutrition content analysis is useful if you're tracking calories or just want to be more informed about your diet. It is also helpful in making smarter food decisions [31].

Table 8a. Estimated energy and nutrient content per serving of Bamboo Shoot Tart

\begin{tabular}{|c|c|c|c|}
\hline \multicolumn{4}{|c|}{ Nutrition Facts } \\
\hline \multicolumn{4}{|c|}{ Servings: 24} \\
\hline \multicolumn{2}{|c|}{ Amount per serving } & & \\
\hline Calories & & \multicolumn{2}{|c|}{111} \\
\hline \multicolumn{4}{|c|}{$\%$ Daily Value* } \\
\hline Total Fat 5 & & \multicolumn{2}{|c|}{$7 \%$} \\
\hline Saturated Fat & & \multicolumn{2}{|c|}{$17 \%$} \\
\hline Cholesterol 3 & & \multicolumn{2}{|c|}{$11 \%$} \\
\hline Sodium 53 & & \multicolumn{2}{|c|}{$2 \%$} \\
\hline Total Carbohydr & $.1 \mathrm{~g}$ & \multicolumn{2}{|c|}{$5 \%$} \\
\hline Dietary Fiber & & \multicolumn{2}{|c|}{$1 \%$} \\
\hline \multicolumn{4}{|c|}{ Total Sugars $9.6 \mathrm{~g}$} \\
\hline \multicolumn{4}{|c|}{ Protein $1.5 \mathrm{~g}$} \\
\hline Vitamin D 5 & & \multicolumn{2}{|c|}{$26 \%$} \\
\hline Calcium 9 & & \multicolumn{2}{|c|}{$1 \%$} \\
\hline Iron $0 \mathrm{mg}$ & & \multicolumn{2}{|c|}{$2 \%$} \\
\hline Potassium 7 & & \multicolumn{2}{|c|}{$2 \%$} \\
\hline \multicolumn{4}{|c|}{$\begin{array}{l}\text { *The } \% \text { Daily Value (DV) tells you how much a nutrient in a food } \\
\text { serving contributes to a daily diet. } 2,000 \text { calories a day is used for } \\
\text { general nutrition advice. }\end{array}$} \\
\hline Nutrient & Content & RENI & $\%$ RENI \\
\hline Energy (kcal) & 111 & 2530 & 4 \\
\hline Protein (g) & 1.5 & 71 & 2 \\
\hline Fat $(\mathrm{g})$ & 5.7 & - & - \\
\hline Carbohydrates (g) & 14.1 & - & - \\
\hline Calcium (mg) & 9 & 750 & 1 \\
\hline Iron (mg) & 0 & 12 & 2 \\
\hline Vitamin D & 5 & 700 & 26 \\
\hline
\end{tabular}

The table reveals the results of Menu Analysis of bamboo shoot tart. The table shows that 1 serving of the product contains 111 calories, $1.5 \mathrm{~g}$ of protein, 5.7 grams fat, 14.1 carbohydrates, $9 \mathrm{mg}$ calcium, and $71 \mathrm{mg}$ potassium.

\section{Discussion}

This study was conducted to assess the sensory quality of Bamboo Shoot Tart as perceived by the consumers with the following objectives: (1) to determine the profile of the respondents as to sex, civil status, ethnic affiliation, age, and highest educational attainment; (2) to assess the sensory quality of the developed bamboo shoot tart as perceived by the respondents in terms of appearance, color, texture, aroma, presentation, and taste; and (3) to verify if there are significant differences on the sensory evaluation of Bamboo Shoot Tart when respondents are grouped by sex, civil status, ethnic affiliation, age, and highest educational attainment along appearance, color, texture, aroma, presentation, and taste. Data were tabulated, analyzed, and interpreted using frequency, percent, mean, t-test, and ANOVA.

The highlights of the study are as follows: thirty five (35) respondents are male while 65 are female. In terms of civil status, seven (7) are married and 93 respondents are single. As to ethnic affiliation, 13 are Tagalog, 60 respondents are Ilocano, 18 are Ifugao, and nine (9) are Bago, Yogad and Igorot. In terms of age, 42 respondents are $17-19$ years old, 49 are $20-22$ years old, and nine (9) are 23 years old $\&$ above. As to highest educational attainment, 90 are in college and 10 are in high school or Master Degree Holder.

In general, the items appearance, texture, and aroma are described as Like Very Much. Meanwhile, the items color, presentation, and taste have a description of Like Extremely. As to sex, the items appearance, color, texture, and presentation for male and the items appearance, texture, and aroma for female have a description of Like Very Much.

On the other hand, the items aroma and taste for male and the items color, presentation, and taste for female are described as Like Extremely. In terms of civil status, the items appearance, color, texture, aroma, and presentation for married and the items appearance, texture, and aroma for single are described as Like Very Much while the item taste for married and the items color, presentation, and taste for single have a description of Like Extremely.

As to ethnic affiliation, the item taste for Tagalog; the items color, presentation, and taste for Ilocano; the items appearance, color, and taste for Ifugao; and the items appearance, color, texture, and taste for Bago, Yogad, and Igorot are described as Like Extremely. In terms of age, the items appearance, color, presentation, and texture for 17 19 years old; and the item taste for $20-22$ and 23 years old $\&$ above are described as Like Extremely.

As to highest educational attainment, the items color and taste for college level and the items presentation and taste for high school level and Master Degree Holder have a description of Like Extremely. Thus, college level respondents like Bamboo shoot Tart extremely as to color and taste. On the other hand, the respondents who are in high school and Master Degree Holder like the product extremely along with presentation and taste.

There are significant differences on the sensory quality of Bamboo Shoot Tart as to color when respondents are grouped by sex and age; as to texture when grouped by ethnic affiliation; and along texture and taste when respondents are grouped by highest educational attainment. 


\section{Conclusions and Future Works}

Most of the respondents are female, single, Ilocano, 20 22 years old, and in college. The respondents like Bamboo Shoot Tart very much along with appearance, texture, and aroma. However, the respondents like Bamboo Shoot Tart extremely as to color, presentation, and taste. As to sex, this implies that male respondents like Bamboo Shoot Tart very much as to appearance, color, texture, and presentation and female respondents like the product very much along appearance, texture, and aroma. However, male respondents like Bamboo Shoot Tart extremely as to aroma and taste while female respondents like the product extremely along color, presentation, and taste. In terms of civil status, married respondents like Bamboo shoot Tart very much along appearance, color, texture, aroma, and presentation and single respondents like the product very much as to appearance, texture, and aroma.

However, married respondents like Bamboo Shoot Tart extremely as to taste while single respondents like the product extremely along color, presentation, and taste. In terms of ethnic affiliation, Tagalog respondents like Bamboo Shoot Tart extremely as to taste; Ilocano along color, presentation, and taste; Ifugao as to appearance, color, and taste; and Bago, Yogad, and Igorot along appearance, color, texture, and taste. In terms of age, the respondents who are 17 - 19 years old like Bamboo Shoot Tart extremely as to appearance, color, presentation, and texture; and the respondents who are $20-22$ and 23 years old \& above like Bamboo Shoot Tart extremely along taste.

The sensory quality of Bamboo Shoot Tart varies as to color when respondents are grouped by sex and age. The sensory quality of the product differs among ethnic groups on texture. Moreover, the sensory quality of Bamboo Shoot Tart varies between college level and high school level/Master Degree Holder.

This study has limits on the analysis of its shelf-life. It is then recommended to the next researcher to determine the shelf life and the microbial analysis to further improve the product. It is also recommended for researchers to combine with qualitative studies to give a more comprehensive and in-depth picture to develop bamboo shoot products to respond to the government's initiative to create and develop products as a way to mitigate poverty in the province. The result of the cost benefit analysis is also promising and has potential for product commercialization.

\section{Acknowledgement}

The Authors would like to thank Quirino State University-Diffun Campus Administration for the approval to conduct the study and the experts of Isabela State University, Philippines and the Conference Committee of 1st International Research Conference in Computing, Engineering, Business, Sciences, and Education (IRCCEBSE) for their appropriate and constructive suggestions to improve this article.

\section{REFERENCES}

[1] Burger Chakraborty, L., Sahakian, M., Rani, U., Shenoy, M., \& Erkman, S. (2016). Urban Food Consumption in Metro Manila: Interdisciplinary Approaches Towards Apprehending Practices, Patterns, and Impacts. Journal of Industrial Ecology, 20(3), 559-570. https://doi.org/10.1111/jiec.12402

[2] D.Choudhury, K. Jatindra Sahu, and G. D. Sharma Jatindra K. Sahu,(2012) J Food Sci Technol. 49(4): 407-414 DOI: 10.1007/s13197-011-0379-z PMID: PMC3550903 Retrieve from http://www.ncbi.nlm.nih.gov/pmc/article/PMC355090 $3 /$

[3] [3] Tariga, Jonathan. N. (2020). Standardization and nutritional content determination of ready-to-eat bamboo shoot dishes. Journal of Critical Reviews, 7(11). https://doi.org/10.31838/jcr.07.11.19

[4] [4, 5] Ruby D. G. Elumbra. (2020). Sensory Evaluation and Acceptability of Bambusa Blumeana As Bamboo Shoot Polvoron. International Journal of Advanced Science and Technology, 29(08), 4769 - 4778. Retrieved from http://sersc.org/journals/index.php/IJAST/article/view/2661

[5] P. Nongdam and Leimapokpam Tikenda The Nutritional Facts of bamboo Shoots and Their Usage as Important Traditional Foods of Northeast India Volume 2014 |Article ID 679073 | https://doi.org/10.1155/2014/679073

[6] Benjamin Acho Amadi, Lynda Nonye Eke, Mathew Owhonda Wegwu, Justice Obinna Osuoha (2018). Nutritional Composition of Three Selected Traditional Diets: A Case Study of Ngwa People in Abia State, Nigeria. Food Science and Technology, 6(1), 1 - 9. DOI: 10.13189/fst.2018.060101.

[7] Nirmala, C., Bisht, M. S. \& Laishram, M. Bioactive compounds in bamboo shoots: health benefits and prospects for developing functional foods. Int. J. Food Sci. Tech. Mys. 49, 1425-1431 (2014).

[8] Satya, S., Singhal, P., Bal, L. M., \& Sudhakar, P. (2011). Bamboo shoot: a potential source of food security. Mediterranean Journal of Nutrition and Metabolism, 5(1), 1-10. doi:10.1007/s 12349-011-0086-3

[9] http://agsyst.wsu.edu/bambroc.pdf

[10] C. Nirmala, M. L. Sharma, and E. David, "A comparative study of nutrient component of freshly harvested, fermented and canned bamboo shoots of Dendrocalamus giganteus Munro," The Journal of the American Bamboo Society, vol. 21, no. 1, pp. 33-39, 2008.

[11] Y. H. Qiuc, X. G. Shaoc, F. G. Zhang, W. L. Hua, and L. W. Bao, "Analysis of physical behaviors and nutrition constituents of Phyllostachys heteroclada bamboo shoots," Journal Zhejang Forestry College, vol. 16, no. 2, pp. 200-202, 1999.

[12] C. J. Chen, E. F. Qiu, R. Z. Huang, H. Fan, and J. X. Jiang, "Study on the spring shoot nutrient content of Phyllostachys 
pubescens of different provinces," Journal of Bamboo Research, vol. 18, pp. 6-11, 1999.

[13] M. L. Sharma, C. Nirmala, and E. David, "Variations in nutrient and nutritional components of juvenile bamboo shoots," Panjab University Research Journal, vol. 54, pp. 101-104, 2004.

[14] P. Singhal, L. M. Bal, S. Satya, P. Sudhakar, and S. N. Naik, "Bamboo shoots: a novel source of nutrition and medicine," Critical Reviews in Food Science and Nutrition, vol. 53, no. 5, pp. 517-534, 2013.

[15] Yang, Y. X. et al. China food composition. Peking University Medical Press 42 (2015).

[16] S. Karnjanapratum, P. Kaewthong, S. takeu ngwongtrakul, T. Sae-leaw, J.H. Hong, S. Nalinanon Production of fiber hydrolysate from bamboo shoot with antioxidative properties by enzymatic hydrolysis. Current Applied Science and Technology, 19(3) (2019), pp. 225-234

[17] Wang, Yulin; Chen, Jia; Wang, Damao; Ye, Fayin; He, Yonglin; Hu, Zicong; Zhao, Guohua (2020). A systematic review on the composition, storage, processing of bamboo shoots: Focusing the nutritional and functional benefits. Journal of Functional Foods, 71(), 104015-. doi:10.1016/j.jff.2020.104015

[18] RFRI (2008). Bamboo as food and medicine. Report of Rain Forest Research Institute (RFRI). Jorhat, India. www.icfre.gov.in/new/rfri/Bamboo_\%20food_\%20medicin e_221206.pdf.

[19] Satya S, Bal ML, Singhal P, Naik SN (2010) Bamboo shoot processing: food quality and safety aspect (a review). Trends in Food Science \& Technology 21: 181-189

[20] Sarkar P, Kumar DHL, Dhumal C, Panigrahi SS, Choudhary R (2015) Traditional and ayurvedic foods of Indian origin. J
Ethn Foods 2(3): 97-109.

[21] K. Visuphaka, "The role of bamboo as a potential food source in Thailand," in Proceedings of the International Bamboo Workshop, pp. 301-303, Recent Research on Bamboos, Hangzhou, China, October 1985.

[22] N. H. Xia, "Analysis of nutritive constituents of bamboo shoots in Guangdong," Acta Botanica Austro Sinica, vol. 4, pp. 199-206, 1989.

[23] Deckard, A (2017) 6 Proven Benefits of Bamboo Shoots Retrieve from https://healthyfocus.org/benefits-of-bamboo-s hoots/benefits-of-bamboo-shoots/

[24] Tomar, S. K. (2016). Fermented Bamboo Shoots: A Riche Niche for Beneficial Microbes. Journal of Bacteriology \& Mycology: Open Access, 2(4). https://doi.org/10.15406/jbm oa.2016.02.00030

[25] Panee J (2015) Potential medicinal application and toxicity evaluation of extracts from bamboo plants. J Med Plants Res 9(23): 681-692.

[26] https://dost.gov.ph/knowledge-resources/downloads/file/791 -harmonized-national-r-d-agenda-2017-2022.html

[27] Bashir T. (2010) Prospects of bamboo shoot processing in north-east India. Curr Sci. 2010; 98(3):288-289.

[28] Santosh Satya; Lalit M. Bal; Poonam Singhal; S.N. Naik (2010). Bamboo shoot processing: food quality and safety $\begin{array}{llll}\text { aspect (a } & \text { review)., } & \text { 21(4), } & 0-189 .\end{array}$ doi:10.1016/j.tifs.2009.11.002

[29] https://www.bakeryandsnacks.com/Article/2014/05/15/Fiber -in-bakery-Science-round-up

[30] https://www.verywellfit.com/recipe-nutrition-analyzer-4157 076 